\title{
Gastroprotective effects of aquous solution: Acacia catechu on gastric mucosal injury in experimental albino rats model
}

\author{
Uzma Waseem $^{1 *}$, Anoosha Waseem ${ }^{2}$, Nadia Majeed ${ }^{3}$, Fauzia Qureshi', \\ Muhammad Qasim Muneer ${ }^{5}$, Syeda Rizwana Jafri ${ }^{4}$
}

\author{
${ }^{1}$ Department of Anatomy, Shalamar Medical and Dental college, Lahore, Punjab, Pakistan \\ ${ }^{2}$ de'Montmorency, College of Dentistry, Lahore, Punjab, Pakistan \\ ${ }^{3}$ Department of Anatomy, Amna Inayat Medical College, Lahore, Punjab, Pakistan \\ ${ }^{4}$ Department of Anatomy, Azra Naheed Medical College, Superior university Lahore, Punjab, Pakistan \\ ${ }^{5}$ Department of Anatomy, Allama Iqbal Medical college, Lahore, Punjab, Pakistan
}

Received: 09 February 2021

Revised: 19 March 2021

Accepted: 20 March 2021

\section{*Correspondence:}

Dr. Uzma Waseem,

Email: uzma.2009.waseem@gmail.com

Copyright: (C) the author(s), publisher and licensee Medip Academy. This is an open-access article distributed under the terms of the Creative Commons Attribution Non-Commercial License, which permits unrestricted non-commercial use, distribution, and reproduction in any medium, provided the original work is properly cited.

\begin{abstract}
Background: Around the globe, acid peptic disease and its potential complications are among the major cause of morbidity and is a significant burden on health system. Till now, the main stay of treatment are the pharmaceutical agents which decrease the secretion of acid. But these have potential complications and tolerability issues. Among such plants one is Acacia catechu commonly available in India and Pakistan.

Methods: This experimental study involved 48 albino rats that were divided into four groups. Group A, B, C, and D were given water, $100 \mathrm{mg}$ aspirin, $100 \mathrm{mg}$ aspirin $+250 \mathrm{mg}$ Acacia catechu and $100 \mathrm{mg}$ aspirin $+500 \mathrm{mg}$ Aacacia catechu respectively, and were sacrificed on day 3,7 and 14th day of study and observed for changes.

Results: Difference between blood vessels in subgroup B1 and subgroup C1 with subgroup D1 was statistically significant $(\mathrm{p}=0.05)$ and $(\mathrm{p}=0.001)$. Group $\mathrm{C} 1$ and $\mathrm{D} 1$ had normal vessels in mucosa and submucosa. However, dilatation of blood vessels was noted in both groups receiving Acacia catechu along with ASA.

Conclusions: Aqueous extracts of Acacia catechu stem and bark showed significant anti-ulcer and anti-inflammatory activities by increasing blood flow to the stomach.
\end{abstract}

Keywords: Acacia catechu, Peptic ulcer, Plant extracts

\section{INTRODUCTION}

Around the globe, acid peptic disease and its potential complications are among the major cause of morbidity and is a significant burden on health system. ${ }^{1-3}$ Till now, the main stay of treatment are the pharmaceutical agents which decrease the secretion of acid. But these have potential complications and tolerability issues. So, it is the need of time to search for the agents with good safety profile. For this purpose, research is going on to look for suitable medicine from plant source. Among such plants, one is Acacia catechu commonly available in India and Pakistan. It is claimed that it has antidiabetic, anti- inflammatory, anti-bacterial, antioxidant, antifungal and antiulcer potential. ${ }^{4-6}$ It contains epicatechin, catechin, flavanoids like kaempferol, dihydrokaempferol and toxifolin. ${ }^{7-11}$

The protective mechanisms of the body against gastric ulcer disease include basic mucus which neutralizes acid, quick epithelial regeneration, high blood flow which will clear oxidative stress, mucosal sulphydral and gland resistance to acid. Gastric ulcer develops when these protective mechanisms are impaired and there is imbalance between protective and destructive mechanisms. Acacia catechu is believed to have anti-ulcer 
properties. It also has antioxidant potential and also increases blood flow. So, by all these mechanisms it protects against gastric ulcers. ${ }^{12-15}$

Despite long-term use of Acacia catechu, there is a need for safety studies in animals and humans. Well-controlled clinical trials are needed regarding its potency and efficacy. This will also in turn prove to have credible economic benefit to the local population of the areas where it is cultivated. The current study was performed to evaluate the protective effects of Acacia catechu on histology of gastric mucosa of albino rats with ASA induced gastric ulcers.

\section{METHODS}

This experimental study took place at Postgraduate Medical Institute, Lahore. Experimental albino rats weighing 150-250g were purchased from the University of
Veterinary and Animal Sciences Lahore and were kept under controlled environment. Aspirin in powdered form was obtained from BDH (British drug houses) Limited Poole England and bark of Acacia catechu was collected from Botany Department of Government College University, Lahore. Ethical permission was taken from the ethical committee of the hospital.

It was dried in shade. Then it was powdered in an electronic grinder, sieved and stored in an air tight container (Pingale). ${ }^{16}$ Group A served as a control and was further subdivided into three groups A1, A2 and A3 which were given $4 \mathrm{ml}$ of distilled water orally for 3, 7 and 14 days, respectively (Eteng et al). ${ }^{17}$ Group B was further subdivided into three groups B1, B2 and B3 which were given aspirin at a dose of $100 \mathrm{mg} / \mathrm{kg}$ body weight, dissolved in $4 \mathrm{ml}$ of distilled water orally for 3, 7 and 14 days, respectively (Kato et al). ${ }^{18}$ Rats were randomly divided using balloting method into groups as described in Table 1.

Table 1: Intervention and dosage schedule in groups A, B, C and D.

\begin{tabular}{|c|c|c|c|c|c|}
\hline Groups & Subgroups & $\begin{array}{l}\text { No. of } \\
\text { animals }\end{array}$ & Intervention and dosage & $\begin{array}{l}\text { Duration of } \\
\text { treatment }\end{array}$ & $\begin{array}{l}\text { Days of } \\
\text { sacrifice }\end{array}$ \\
\hline \multirow{3}{*}{$\begin{array}{l}\text { Group A } \\
\text { (Control) }\end{array}$} & A1 & 4 & \multirow{3}{*}{$4 \mathrm{ml}$ of distilled water, orally } & 3 days & 3 \\
\hline & $\mathrm{A} 2$ & 4 & & 7 days & 7 \\
\hline & A3 & 4 & & 14 days & 14 \\
\hline \multirow{3}{*}{ Group B } & $\mathrm{B} 1$ & 4 & \multirow{3}{*}{$\begin{array}{l}\text { ASA } 100 \mathrm{mg} / \mathrm{kg} \text { dissolved in } 4 \mathrm{ml} \text { of } \\
\text { distilled water, orally }\end{array}$} & 3 days & 3 \\
\hline & $\mathrm{B} 2$ & 4 & & 7 days & 7 \\
\hline & B3 & 4 & & 14 days & 14 \\
\hline \multirow{3}{*}{ Group C } & $\mathrm{C} 1$ & 4 & \multirow{3}{*}{$\begin{array}{l}\text { ASA } 100 \mathrm{mg} / \mathrm{kg}+\text { Acacia catechu } 250 \mathrm{mg} / \mathrm{kg} \\
\text { dissolved in } 4 \mathrm{ml} \text { of distilled water, orally }\end{array}$} & 3 days & 3 \\
\hline & $\mathrm{C} 2$ & 4 & & 7 days & 7 \\
\hline & $\mathrm{C} 3$ & 4 & & 14 days & 14 \\
\hline \multirow{3}{*}{ Group D } & D1 & 4 & \multirow{3}{*}{$\begin{array}{l}\text { ASA } 100 \mathrm{mg} / \mathrm{kg}+\text { Acacia catechu } 500 \mathrm{mg} / \mathrm{kg} \\
\text { dissolved in } 4 \mathrm{ml} \text { of distilled water, orally }\end{array}$} & 3 days & 3 \\
\hline & D2 & 4 & & 7 days & 7 \\
\hline & D3 & 4 & & 14 days & 14 \\
\hline
\end{tabular}

Four animals from each subgroup were anaesthetized with chloroform (Holmer and Tronier, 2002). Their stomachs were dissected and examined.

\section{Statistical analysis}

SPSS 20 (statistical package for social sciences) was used for analysis. Mean \pm SD was calculated for quantitative variables (ulcer index, blood vessels, inflammatory cells, fibroblasts and collagen content in the mucosa and submucosa of stomach).

One-way ANOVA was applied to compare means of histological and gross quantitative parameters among the control and experimental groups. Post hoc Tukey test was used for multiple comparisons. Chi square test was being used to determine the association of qualitative variable (ulcer depth) within the groups. $\mathrm{P}$ value of $\leq 0.05$ was considered as statistically significant.

\section{RESULTS}

Blood vessels were counted in mucosa at the ulcer base and submucosa underlying it.

On day 3, in subgroup A1 normal capillaries in mucosa and small arterioles and venules in submucosa were noted that were not congested. Number of blood vessels in group B1 was small out of which most were dilated, congested and disrupted. Dilatation of blood vessels was noted in subgroup $\mathrm{C} 1$ that had the highest number in all four groups (14 and 15). Slightly dilated blood vessels were noted in subgroup D1.

On day 7, blood vessels in A2 were normal and not congested. Number of blood vessels in B2 failed to increase. Blood vessels were disrupted with an increase amount of connective around them. Blood vessels were dilated but showed an intact architecture in subgroup C2 and subgroup D2. 
On day 14 , the blood vessels in control group were normal. Blood vessels in subgroup B3 were disrupted with an increase amount of connective tissue around them. However, normal but dilated vessels in mucosa and submucosa of subgroup C3 and subgroup D3 were seen.
Mean number of blood vessels in control and experimental groups is shown in Table 2.

On using one-way ANOVA, statistically significant difference was observed among the groups $\mathrm{p}$ value $<0.000^{*}$ (Table 3).

Table 2: Descriptive statistics of blood vessels and comparison in different study groups.

\begin{tabular}{|lllllll|} 
& Days & $\begin{array}{l}\text { Group A1 } \\
\text { Mean } \pm \text { SD }(n=4)\end{array}$ & $\begin{array}{l}\text { Group B1 } \\
\text { Mean } \pm \text { SD }(n=4)\end{array}$ & $\begin{array}{l}\text { Group C1 } \\
\text { Mean } \pm S D(n=4)\end{array}$ & $\begin{array}{l}\text { Group D1 } \\
\text { Mean } \pm S D(n=4)\end{array}$ & P value \\
\hline $\begin{array}{l}\text { No. of } \\
\text { Blood } \\
\text { vessel }\end{array}$ & 3rd day & $4.75 \pm 1.50$ & $3.75 \pm 0.96$ & $12.75 \pm 1.50$ & $7.50 \pm 1.00$ & $<0.001^{*}$ \\
\cline { 2 - 7 } & 7th day & $3.75 \pm 0.96$ & $8.25 \pm 1.71$ & $21.00 \pm 1.41$ & $11.5 \pm 1.29$ & $<0.001^{*}$ \\
\hline
\end{tabular}

*p value $\leq 0.05$ is statistically significant.

Table 3: Blood vessels: multiple/paired wise comparison using Post hoc Tukey test.

\begin{tabular}{|c|c|c|c|c|}
\hline Time of Sacrifice & (I) Study groups & (J) Study groups & Mean difference (I-J) & P value \\
\hline \multirow{6}{*}{ 3rd day } & \multirow{3}{*}{ Group-A } & Group-B & 1.000 & 0.082 \\
\hline & & Group-C & -8.000 & $<0.000^{*}$ \\
\hline & & Group-D & -2.750 & $<0.329$ \\
\hline & \multirow{2}{*}{ Group-B } & Group-C & -9.000 & $0.000 *$ \\
\hline & & Group-D & -3.750 & $0.047 *$ \\
\hline & Group-C & Group-D & 5.250 & $0.001 *$ \\
\hline \multirow{6}{*}{ 7th day } & \multirow{3}{*}{ Group-A } & Group-B & -4.500 & $0.000 *$ \\
\hline & & Group-C & -17.250 & $0.000 *$ \\
\hline & & Group-D & -7.7500 & $0.000 *$ \\
\hline & \multirow{2}{*}{ Group-B } & Group-C & -12.750 & $0.000 *$ \\
\hline & & Group-D & -3.2500 & 0.137 \\
\hline & Group-C & Group-D & 9.500 & $0.000 *$ \\
\hline \multirow{6}{*}{ 14th day } & \multirow{3}{*}{ Group-A } & Group-B & -8.000 & $0.000 *$ \\
\hline & & Group-C & -18.250 & $0.000 *$ \\
\hline & & Group-D & -10.000 & $0.000 *$ \\
\hline & \multirow{2}{*}{ Group-B } & Group-C & -10.250 & $0.000 *$ \\
\hline & & Group-D & -2.000 & 0.767 \\
\hline & Group-C & Group-D & 8.250 & $0.000 *$ \\
\hline
\end{tabular}

$*$ p value $\leq 0.05$ is statistically significant.

After applying post hoc Tukey test, on day 3, the number of blood vessels in subgroup B1 was not statistically significant as compared to control subgroup A1 $(\mathrm{p}=1.000)$. Subgroup CI showed a statistically significant difference as compared to subgroup A1 and subgroup B1 ( $\mathrm{p}=0.000)$. Blood vessel count in subgroup D1 was not statistically significant as compared to subgroup A1 $(p=0.329)$. Difference between blood vessels in subgroup B1 and subgroup C1 with subgroup D1 was statistically significant $(p=0.05)$ and $(p=0.001)$. Group $\mathrm{C} 1$ and D1 had normal vessels in mucosa and submucosa. However, dilatation of blood vessels was noted in both groups receiving Acacia catechu along with ASA (Table 3).

On day 7, the blood vessel count in subgroup A2 was statistically significant as compared to group B2 $(\mathrm{P}=0.008), \mathrm{C} 2$ and D2 $(\mathrm{p}=0.000)$. Statistically significant difference was noted in subgroup $\mathrm{C} 2$ as compared to subgroup B2 and subgroup D2 $(\mathrm{P}=0.000)$. However, subgroup B2 and subgroup D2 did not show any statistically significant difference $(\mathrm{p}=0.137)$ (Table 3$)$.
On day 14, the number of blood vessels in subgroup A3 was significant as compared to subgroup B3, subgroup C3 and subgroup D3 ( $(\mathrm{p}=0.000)$. Difference between subgroup B3, subgroup C3 and subgroup D3 ( $\mathrm{p}=0.000)$ was also noted (Table 3).

\section{DISCUSSION}

Number of blood vessels in subgroup B1 was not significant as compared to control subgroup A1. Following a therapeutic dose of ASA, the first histological change in rat stomach is distortion of basement membrane of the endothelium of the capillaries and small venules leading to the breakdown of small blood vessels. ${ }^{19}$ Micro vessels are lined by endothelial cells that produce nitric oxide (NO) and prostacyclin which act as strong vasodilators. They protect the gastric mucosa and counteract the negative effects of vasoconstrictors, including endothelin (Laine et) ${ }^{20}$ Inhibition of COX-1, results in release of endothelin, which is known to induce gastric mucosal injury in rats. ${ }^{21}$ Exposure of gastric mucosa to NSAIDS leads to acid back- 
diffusion after mucosal injury. As a result, immense increase in mucosal blood flow occurs. ${ }^{22}$ This leads to invasion of circulating neutrophils at the site of injury. Neutrophils adhere to endothelium of blood vessels and block the micro vessels and cause a local decrease in mucosal blood flow. Release of proteolytic enzymes, leukotrienes and endothelin-1 increases the vascular tone and aggravates tissue ischemia. This results in production of ROS which causes immense degree of focal tissue necrosis. ${ }^{23}$

Blood vessels in subgroups C1and D1 receiving Acacia catechu were dilated. Phytochemicals in plant extracts used for the treatment of gastric ulcers lead to an increase in prostaglandin E2 release. PG E2 is a potent vasodilator and hence increases mucosal blood flow. It functions in the stomach through EP2/EP4 and IP receptors. ${ }^{24}$

Prostaglandins also inhibit mast cell stimulation as well as adhesion of leukocytes and platelets to the vascular endothelium (Halter et al, Brzozowski et al). ${ }^{25}$ Coxibs are selective COX-2 inhibitors. They prevent gastric mucosal damage by conserving COX-1-dependent prostaglandin production that maintains gastric blood flow. ${ }^{26}$ Altavilla et al conducted an experiment using flavocoxid which is a compound composed of Baicalin from Scutellaria baicalensis and catechin from Acacia catechu. He used flavocoxid to observe its effect in macrophages stimulated by endotoxin. It was found that flavocoxid inhibited COX2 and 5-lipoxygenase. No effect on COX-1 production was noted. ${ }^{27}$

Day 7: Number of blood vessels failed to increase significantly on day 7 in subgroup B2 as compared to subgroup A2. Blood vessels were disrupted with an increased amount of connective tissue around them. Healing phase of ulcer occurs from 3 to 10 days after ingestion of NSAIDs. Formation of new blood vessels occurs in ulcer bed in later part of healing phase when the inflammatory cells are replaced by fibroblasts and micro vessels. ${ }^{28}$ It has already been evaluated that indomethacin significantly reduces the number of micro vessels in the granulation tissue of ulcer base in experimental animals. NSAIDs inhibit angiogenesis by decreasing prostaglandin synthesis induced by COX inhibition. ${ }^{29}$ NSAIDs suppress cell cycle proteins leading to arrest in proliferation of endothelial cells. This results in decrease in VEGF, increased apoptosis of endothelial cells and inhibition of migration of endothelial cells to form new vessels. ${ }^{30}$ Blood vessel count in subgroups C2 and D2 was showed a significant increase as compared to subgroup A2. Normal, but slightly dilated blood vessels in mucosa and submucosa of subgroups C1 and D1 while the number was highest in subgroup C2. Following gastric ulcerative offense, vessels undergo destruction within the necrotic area. Restitution of mucosal micro vessels is vital for delivery of oxygen and nutrients to the healing site. ${ }^{31}$ Pro-inflammatory cytokines like TNF- $\alpha$ is released as a result of tissue injury. TNF- $\alpha$ reduces expression of VEGF in wound sites hence inhibiting angiogenesis. Increased regeneration of blood capillaries at ulcer site in subgroups C2 and D2 might be due to decreased gene expression of TNF- $\alpha$. Tseng- Crank et al. ${ }^{32}$ evaluated the anti-inflammatory activity of a blend of scutellaria baicalensis and Acacia catechu in animal and human cell lines. The product suppressed proinflammatory genes for cyclooxygenase, tumor necrosis factor, IL-1 $\beta$, and IL-6 and nuclear factor - kappa B (NF$\mathrm{kB})$.

Day 14: Presence of eroded arteries trapped in fibrous tissue, were noted in aspirin group. The increased incidence of ulcerations after aspirin administration might result from decreased mucosal blood flow produced by increased deposition of connective tissue (collagen fibers) in lamina propria mainly around blood vessels. This study goes with work done by Kang et al on age-related changes impairment in gastric blood flow in rats. ${ }^{33}$ They showed that mucosal ulceration might result from marked fibrosis around blood vessels. In cases of chronic hypoxia, small pulmonary arteries demonstrated narrowing of the vascular lumen which is attributed to increased production of extracellular matrix proteins (type I collagen and elastin) by fibroblasts. ${ }^{34}$ Vessel count in C3 and D3 showed significant increase as compared to control group A3. Zhang et al used histochemistry, immunohistochemistry and Western blot to observe the changes of appearance and SOD expression in vascular tissues after balloon injury in rats. Flavonoids can augment the antioxidant capacities of vessel tissues by suppressing the formation of ROS. ${ }^{34}$

\section{CONCLUSION}

In the light of previous studies on herbal drugs and findings of our study, it was considered worthwhile to investigate the anti-ulcer and anti-inflammatory activity of Acacia catechu. Aqueous extracts of Acacia catechu stem and bark showed significant anti-ulcer and anti-inflammatory activities by increasing blood flow to the stomach. Therefore, the current study provides initial data on the antiulcer activity of Acacia catechu bark and supports its traditional uses. The duration of study was 14 days. It is still not clear whether aqueous solution of bark of Acacia catechu is effective in prolonged treatment with acetylsalicylic acid and on healing process of preexisting gastric ulcers.

\section{Recommendations}

Further research with extracts prepared with ethyl acetate, ethanol, and methanol on gastric mucosa should be evaluated. The main chemical constituents of Acacia catechu such as flavonoids, alkaloids and tannins have been shown to possess multiple medicinal properties. It is posited in this in this study that protective effects of Acacia catechu are due to its antioxidant properties. Future researches should focus on biochemical assays to show that there was reduced oxidative stress in Acacia catechu treated animals. Although Acacia catechu has been used for years in traditional medicine, there is still a need for 
well-controlled animal and human studies to evaluate its safety and efficacy.

Funding: No funding sources

Conflict of interest: None declared

Ethical approval: The study was approved by the Institutional Ethics Committee

\section{REFERENCES}

1. Abebaw M, Mishra B, Gelayee DA. Evaluation of anti-ulcer activity of the leaf extract of Osyris quadripartita Decne.(Santalaceae) in rats. J of exper Pharmacol. 2017;9:1-11.

2. Khare b, Dubey N, Sharma a. Antiulcer activity of controlled release formulation containing aqueous extract of acacia catechu willd on rodent models. Int J Curr Pharm Res. 2018;10(5):25-31.

3. Alam G, Singh MP, Singh A, Patel R. Investigation of anthelmintic, anti-inflammatory activity of leaves extract of Acacia catechu Willd. J Pharm Res. 2012;5(5):2587-9.

4. Alambayan J, Vats M, Sardana S, Sehrawat R. Evaluation of antiulcer activity of roots of Acacia catechu Willd.(Mimosoideae). J Pharmacogn Phytochem. 2015;3(5):79-84.

5. Anand TJ, Manjula RR, Ali SL, Sai MH, Padmaja V. Anti-ulcer activity of physalis minima plant extract in albino rats. Int $\mathrm{J}$ Pharmaceut Sci Res. 2013;4(12):4615-8.

6. Alam S, Hussain MS, Reddy MK, Reddy M, Gupta RK. Antiulcer and Antioxidant Potential of Zizyphus jujuba Mill Root Extract In Aspirin And Ethanol Induced Gastric Ulcers. Ind J Pharmacol. 2016;8:28793.

7. Thendral T, Lakshmi T. Antifungal activity of Acacia catechu bark extract against dermatophytes: An in vitro study. J Adv Pharm Edu Res. 2017;7:25-7.

8. Thendral T, Lakshmi T. Antifungal activity of acacia catechu bark extract against dermatophytes: an in vitro study. J Adv Pharm Edu Res. 2017;7:25-7.

9. Thakur AV, Ambwani S, Ambwani TK. Preliminary phytochemical screening and GC-MS analysis of leaf extract of Acacia catechu (Lf) Willd. Int J Herb Med. 2018;6(2):81-5.

10. Park JU, Kang JH, Rahman MA, Hussain A, Cho JS, Lee YI. Gastroprotective effects of plants extracts on gastric mucosal injury in experimental spraguedawley rats. Bio Med Res Int. 2019;2019:1-11.

11. Sattar A, Abdo A, Mushtaq MN, Anjum I, Anjum A. Evaluation of Gastro-protective Activity of Myristica fragrans on Ethanol-induced Ulcer in Albino Rats. Anais da Academia Brasileira de Ciências. 2019;91(2):1-8.

12. Sharifi-Rad M, Fokou PV, Sharopov F, Martorell M, Ademiluyi AO, Rajkovic J, et al. Antiulcer agents: From plant extracts to phytochemicals in healing promotion. Molecules. 2018; 23(7):1751.

13. Jayachitra C, Jamuna S, Ali MA, Paulsamy S, AlHemaid FM. Evaluation of traditional medicinal plant,
Cissus setosa Roxb.(Vitaceae) for antiulcer property. Saudi J Biolog Sci. 2018;25(2):293-7.

14. Zargoosh Z, Ghavam M, Bacchetta G, Tavili A. Effects of ecological factors on the antioxidant potential and total phenol content of Scrophularia striata Boiss. Scient Rep. 2019;9(1):1-5.

15. Barbouchi M, Elamrani K, El Idrissi M. A comparative study on phytochemical screening, quantification of phenolic contents and antioxidant properties of different solvent extracts from various parts of Pistacia lentiscus L. J King Saud Uni Sci. 2020;32(1):302-6.

16. Pingale SS. Hepatoprotection by Acacia catechu in CCl4 induced liver dysfunction. Int J Pharm Sci Rev Res. 2010;5:150-4.

17. Eteng MU, Ibekwe HA, Amatey TE, Bassey BJ, Uboh FU, Owu DU. Effect of vitamin C on serum lipids and electrolyte profile of albino wistar rats. Nig J Physiolog Sci. 2006;21(1-2).

18. Kato S, Suzuki K, Ukawa H, Komoike Y, Takeuchi K. Low gastric toxicity of nitric oxide-releasing aspirin, NCX-4016, in rats with cirrhosis and arthritis. Digest Diseas Sci. 2001;46(8):1690-9.

19. Lee M, Age-related changes in gastric blood flow in rats. Gerontology. 1996;42(5):289-93.

20. Laine L, Takeuchi K, Tarnawski A. Gastric mucosal defense and cytoprotection: bench to bedside. Gastroenterology. 2008;135(1):41-60.

21. Wallace JL, McKnight W, Reuter BK, Vergnolle N. NSAID-induced gastric damage in rats: requirement for inhibition of both cyclooxygenase 1 and 2 . Gastroenterology. 2000;119(3):706-14.

22. Holzer P. Neural regulation of gastrointestinal blood flow. In: Physiology of gastrointestinal tract. Johnson LR. 2006;817-39,

23. Jimenez MD, Martin MJ, Alarcón De La Lastra C, Bruseghini L, Esteras A, Herrerías JM, et al. Role of L-arginine in ibuprofen-induced oxidative stress and neutrophil infiltration in gastric mucosa. Free Radic Res. 2004;38(9):903-11.

24. Kotani T, Kobata A, Nakamura E, Amagase K, Takeuchi K. Roles of cyclooxygenase-2 and prostacyclin/IP receptors in mucosal defense against ischemia/reperfusion injury in mouse stomach. $\mathbf{J}$ Pharmacol Experiment Therapeut. 2006;316(2):54755.

25. Brzozowski T, Konturek PC, Konturek SJ, Brzozowska I, Pawlik T. Role of prostaglandins in gastroprotection and gastric adaptation. J Physiol Pharmacol. 2005;56(5):33-55.

26. Wallace JL. COX-2: a pivotal enzyme in mucosal protection and resolution of Inflammation. Sci W J. 2006;25(6):577-88.

27. Altavilla D, Squadrito F, Bitto A, Polito F, Burnett BP, Di Stefano V, et al. Flavocoxid, a dual inhibitor of cyclooxygenase and 5-lipoxygenase, blunts proinflammatory phenotype activation in endotoxinstimulated macrophages. Brit J Pharmacol. 2009;157(8):1410-8. 
28. Kumar V, Abbas AK, Fausto N, Aster JC. Robbins and Cotran pathologic basis of disease, professional edition e-book. Elsevier Heal Sci. 2014.

29. Tarnawski AS, Jones MK. Inhibition of angiogenesis by NSAIDs: molecular mechanisms and clinical implications. J Molecul Med. 2003;81(10):627-36.

30. Tarnawski AS. Cellular and molecular mechanisms of gastrointestinal ulcer healing. Dig Dis Sci. 2005;50(1):S24-33.

31. Tseng-Crank J, Sung S, Jia Q, Zhao Y, Burnett B, Park DR, et al. A medicinal plant extract of scutellaria baicalensis and acacia catechu reduced LPSstimulated gene expression in immune cells: a comprehensive genomic study using QPCR, ELISA, and microarray. J Diet Supplem. 2010;7(3):253-72.

32. Kang JM, Kim N, Kim JH, Oh E, Lee BY, Lee BH, et al. Effect of aging on gastric mucosal defense mechanisms: ROS, apoptosis, angiogenesis, and sensory neurons. Am J Physiol-Gastrointest Liver Physiol. 2010;299(5):G1147-53.

33. Ooi CY, Wang Z, Tabima DM, Eickhoff JC, Chesler NC. The role of collagen in extralobar pulmonary artery stiffening in response to hypoxia-induced pulmonary hypertension. Am J Physiol-Heart Circulat Physiol. 2010;299(6):H1823-31.

34. Zhang SY, Zheng CG, Yan XY, Tian WX. Low concentration of condensed tannins from catechu significantly inhibits fatty acid synthase and growth of MCF-7 cells. Biochem Biophys Res Communicat. 2008;371(4):654-8.

Cite this article as: Waseem $\mathrm{U}$, Waseem A, Majeed N, Qureshi F, Muneer MQ, Jafri SR.

Gastroprotective effects of aquous solution; Acacia catechu on gastric mucosal injury in experimental albino rats model. Int $\mathrm{J}$ Basic Clin Pharmacol 2021; 10:347-52. 